Singh, B. \& Mitchison, D. A. (1955). J. gen. Microbiol. 13, 176-184.

\title{
The Bactericidal Activities of Combinations of Strepto- mycin, Isoniazid, p-Aminosalicylic Acid (PAS), Oxy- tetracycline (Terramycin) and Viomycin against Mycobacterium tuberculosis
}

\author{
By BALBIR SINGH* AND D. A. MITCHISON $\dagger$ \\ Department of Bacteriology, Postgraduate Medical School of London, \\ Ducane Road, London, W. 12
}

\begin{abstract}
SUMMARY: The bactericidal activities of mixtures of various chemotherapeutic drugs were tested against the $\mathbf{H 3 7} \mathrm{Rv}$ strain of Mycobacterium tuberculosis when growing in Tween albumin medium. Oxytetracycline (terramycin) antagonized the bactericidal activities of streptomycin, isoniazid and viomycin, whereas $p$-aminosalicylic acid (PAS) was slightly synergistic or did not influence their activities. Mixtures of viomycin and streptomycin were slightly less bactericidal than streptomycin alone, but more bactericidal than viomycin alone. Viomycin acted synergistically with isoniazid, and with isoniazid + streptomycin. The emergence of strains resistant to streptomycin, isoniazid or viomycin was not prevented in the cultures by the presence of oxytetracycline, probably because of its rapid inactivation. Drug resistance emerged in dual mixtures which included PAS, where the concentrations of streptomycin, isoniazid or PAS were low, but not when these concentrations were high. Resistant strains did not emerge in cultures containing viomycin + streptomycin or viomycin + isoniazid.
\end{abstract}

Streptomycin, isoniazid and $p$-aminosalicylic acid (PAS) are the compounds most commonly used chemotherapeutically in the treatment of tuberculosis and they were given simultaneously in pairs, or all three together, with the aim of preventing or delaying the emergence of resistant strains of tubercle bacilli. When the strains isolated from patients before treatment are resistant to two or more of these compounds, it has been suggested that combined treatment with compounds, which include oxytetracycline (terramycin) or viomycin, should be used. Hobby, Lenert, Donikian \& Pikula (1951 b) observed that oxytetracycline inhibited the growth of strains of Mycobacterium tuberculosis, both sensitive and resistant to streptomycin to an equal extent. They also found that it had limited activity in suppressing experimental tuberculosis in mice. Oxytetracycline alone has been found to have little therapeutic effect on patients with pulmonary tuberculosis (Pfefer, Hughes \& Dye, 1952; Soderholm, 1952). However, Miller, Sands, Walker, Dye \& Tempel (1952), Des Autels (1953), Miller, Sands, Gregory, Hightower, Weisser \& Tempel (1954) and Rothstein \& Johnson (1954) have shown that oxytetracycline + streptomycin was as effective as streptomycin + PAS or as streptomycin +isoniazid in preventing the emergence of streptomycin-resistant organisms. Furthermore, Stewart, Turnbull \& Crofton (1955) showed that oxytetracycline + isoni-

* Colombo Plan Fellow.

$\dagger$ In receipt of a grant from the Medical Research Council. 
azid effectively suppressed the emergence of isoniazid resistance in strains which were initially resistant to streptomycin, to PAS, or to both of these compounds.

Viomycin was found to be equally bacteriostatic against streptomycin sensitive and resistant strains of tubercle bacilli by Steenken \& Wolinsky (1951), Hobby, Lenert, Donikian \& Pikula (1951 a) and Karlson \& Gainer (1951). Viomycin had an effect on experimental tuberculosis in guinea-pigs and mice comparable to that of a dose of streptomycin four times smaller (Steenken \& Wolinsky, 1951; Youmans \& Youmans, 1951). Drug resistance to viomycin was observed by Werner, Tompsett, Muschenheim \& McDermott (1951). Clinical trials of viomycin + PAS (Hackney, King, Marshall, Harden \& Payne, 1953; Pitts, O'Dell, Fitzpatrick, Dye, Hughes \& Tempel, 1953; Hobby, 1953) indicated an action similar to that of streptomycin + PAS, but superior to that of streptomycin, PAS or viomycin alone.

Reasons for considering that the bactericidal activity of a chemotherapeutic substance or a mixture of such substances is one of the best tests of therapeutic efficiency have been given elsewhere (Mitchison, 1954; Singh, 1954). In vitro experiments on the bactericidal activity of mixtures of oxytetracycline + streptomycin or + penicillin against organisms other than tubercle bacilli showed that oxytetracycline inhibited the bactericidal action of the other component of the mixture (Jawetz, Gunnison \& Speck, 1951; Gunnison, Coleman \& Jawetz, 1950). Mackaness \& Smith (1953) found that, in vitro, oxytetracycline abolished the bactericidal action of isoniazid against tubercle bacilli. The present communication reports an investigation of the bactericidal activity against Mycobacterium tuberculosis of mixtures of oxytetracycline + streptomycin, isoniazid or viomycin, and of viomycin + isoniazid, streptomycin or PAS. Observations have also been made on the ability of these mixtures to suppress the emergence of drug-resistant strains in vitro.

\section{METHODS}

The method of testing the bactericidal action of the compounds was described previously (Singh \& Mitchison, 1954, 1955). The compounds were added to Tween albumin cultures of the $\mathbf{H} 37 \mathbf{R v}$ strain of Mycobacterium tuberculosis so that the final concentrations approximated to those found in the serum of patients treated with usual therapeutic doses. Surface viable counts on oleic acid + albumin agar were then carried out at intervals from these cultures. Sensitivity tests to streptomycin, isoniazid and PAS were done by the Medical Research Council (1953) method. Viomycin and oxytetracycline sensitivity tests were performed by methods similar to those used for streptomycin sensitivity tests.

\section{RESULTS}

\section{Bactericidal activities}

Fig. 1 shows the bactericidal activities of oxytetracycline $10 \mu \mathrm{g}$. $/ \mathrm{ml}$., isoniazid $2 \mu \mathrm{g} . / \mathrm{ml}$. and of a mixture of these concentrations of oxytetracycline and isoniazid. Oxytetracycline alone had no bactericidal action, but inhibited the 
growth of the bacilli for 10 days. After 10 days growth occurred, presumably due to inactivation of the oxytetracycline (Bryson \& Demerec, 1950; Regna \& Solomon, 1950). Isoniazid alone had a well-marked bactericidal action, but in the presence of oxytetracycline there was no significant decrease in the viable count until after the 10th day.

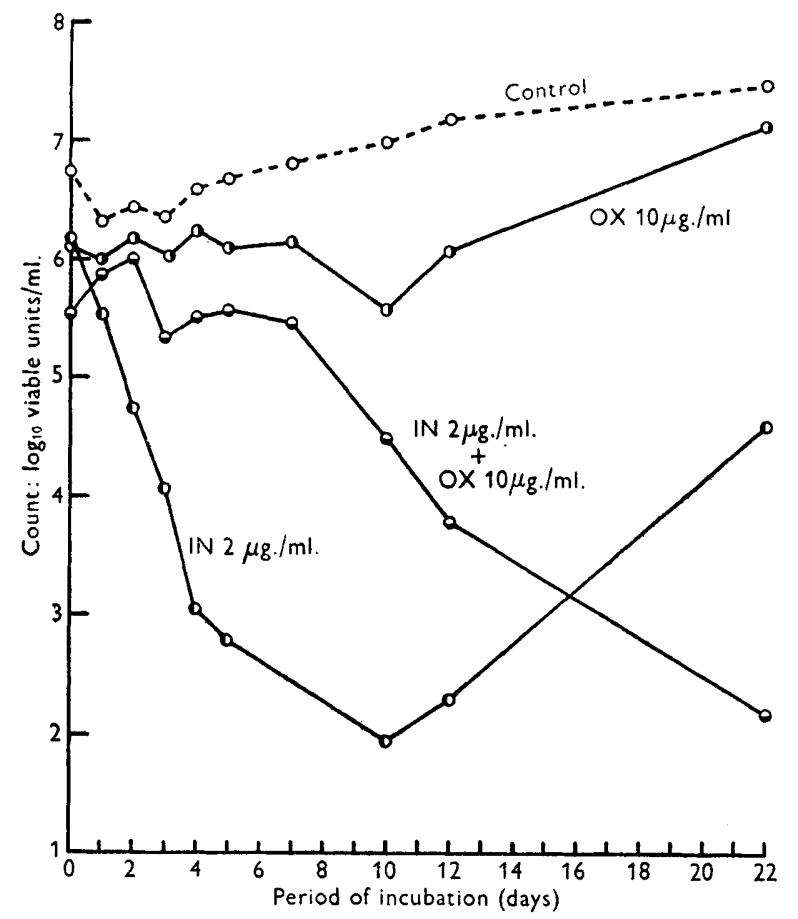

Fig. 1. Bactericidal activities of isoniazid and oxytetracycline, alone and in combination. IN = isoniazid ; OX = oxytetracycline.

Fig. 2 shows an experiment with isoniazid $2 \mu \mathrm{g}$. $/ \mathrm{ml}$. alone, or mixed with oxytetracycline $10 \mu \mathrm{g} . / \mathrm{ml}$., or PAS (sodium salt) $100 \mu \mathrm{g} . / \mathrm{ml}$. Similar mixtures with streptomycin 20 units $/ \mathrm{ml}$. were also set up. Here again, oxytetracycline prevented the bactericidal action of isoniazid for $\boldsymbol{\gamma}$ days, but the bactericidal action of streptomycin was decreased to a lesser extent. In contrast, PAS had a slightly synergistic bactericidal action, more marked with streptomycin than with isoniazid.

Mixtures that included viomycin were set up in the experiment shown in Figs. 3-5. Fig. 3 shows the bactericidal activity of viomycin $40 \mu \mathrm{g} . / \mathrm{ml}$. alone and with oxytetracycline $10 \mu \mathrm{g} . / \mathrm{ml}$., or PAS (sodium salt) $100 \mu \mathrm{g} . / \mathrm{ml}$. For comparison, the culture containing isoniazid $2 \mu \mathrm{g} . / \mathrm{ml}$. is also included, and it can be seen that viomycin alone had approximately the same activity as isoniazid. Oxytetracycline again prevented the bactericidal activity of viomycin during the first 7 days, but PAS had no demonstrable antagonistic or synergistic effect. 


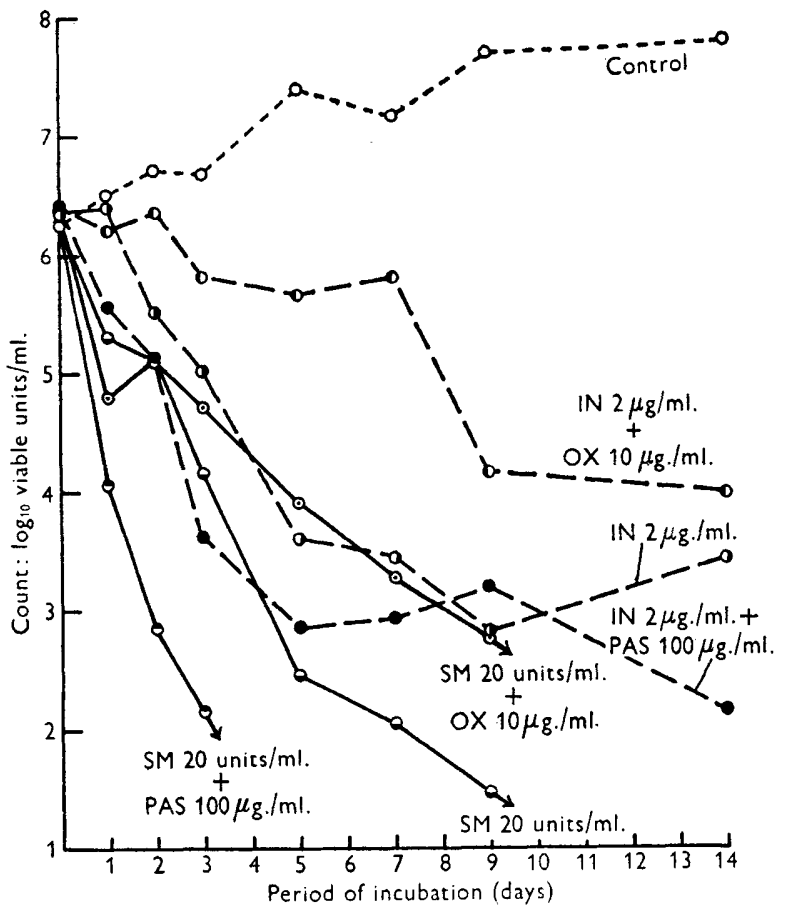

Fig. 2. Bactericidal activities of isoniazid or streptomycin, alone or in combination with oxytetracycline or PAS. IN=isoniazid; $\mathbf{S M}=$ streptomycin; $\mathrm{OX}=$ oxytetracycline; PAS $=p$-aminosalicylic acid (sodium salt).

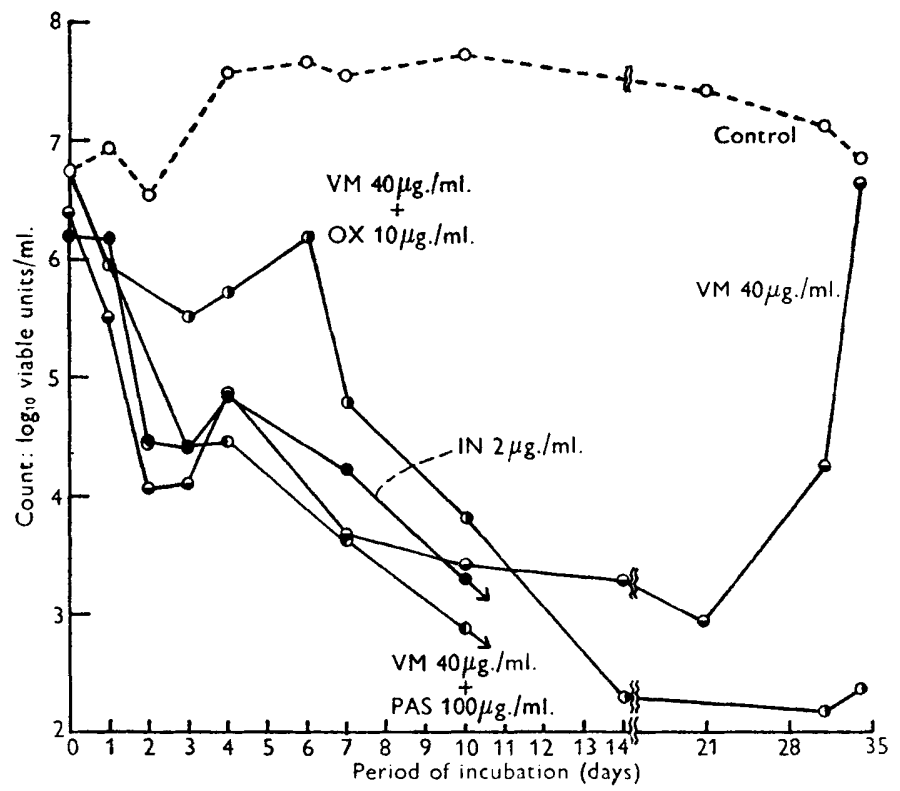

Fig. 3. Bactericidal activities of viomycin, alone or in combination with oxytetracycline or PAS. IN = isoniazid; $\mathrm{VM}=$ viomycin; $\mathrm{OX}=$ oxytetracycline; $\mathrm{PAS}=p$-aminosalicylic acid (sodium salt). 
Fig. 4 shows the activities of viomycin $40 \mu \mathrm{g} . / \mathrm{ml}$. alone, streptomycin $20 \mathrm{units} / \mathrm{ml}$. alone and the two substances together. Viomycin was less bactericidal than streptomycin. In mixture, viomycin appeared to decrease the activity of streptomycin, although the degree of antagonism was so small as to be of doubtful significance; the mixture was, however, more bactericidal than viomycin alone.

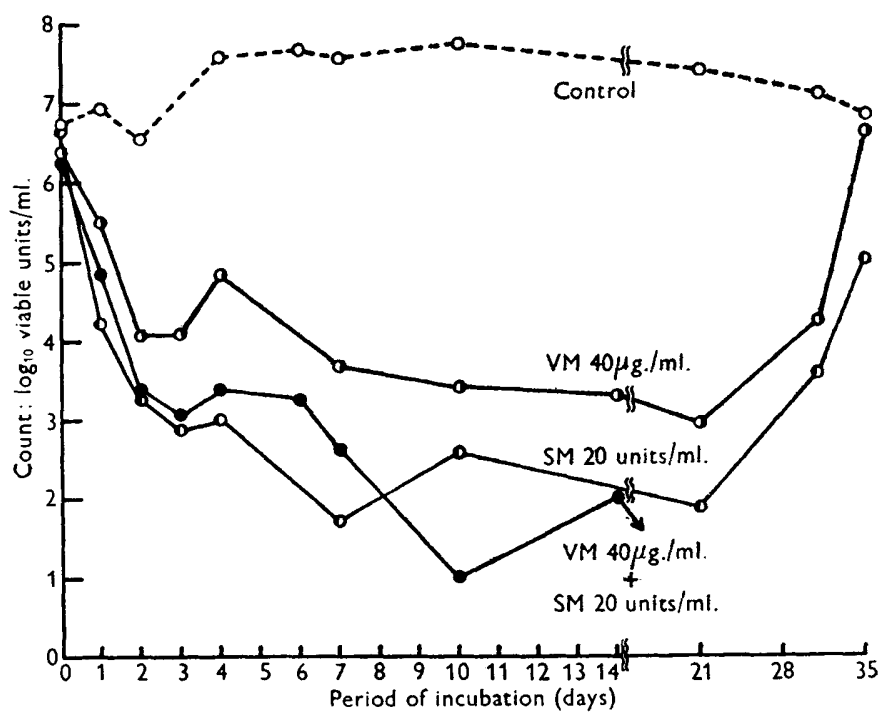

Fig. 4. Bactericidal activities of viomycin and streptomycin, alone and in combination. $\mathbf{V M}=$ viomycin $; \mathbf{S M}=$ streptomycin .

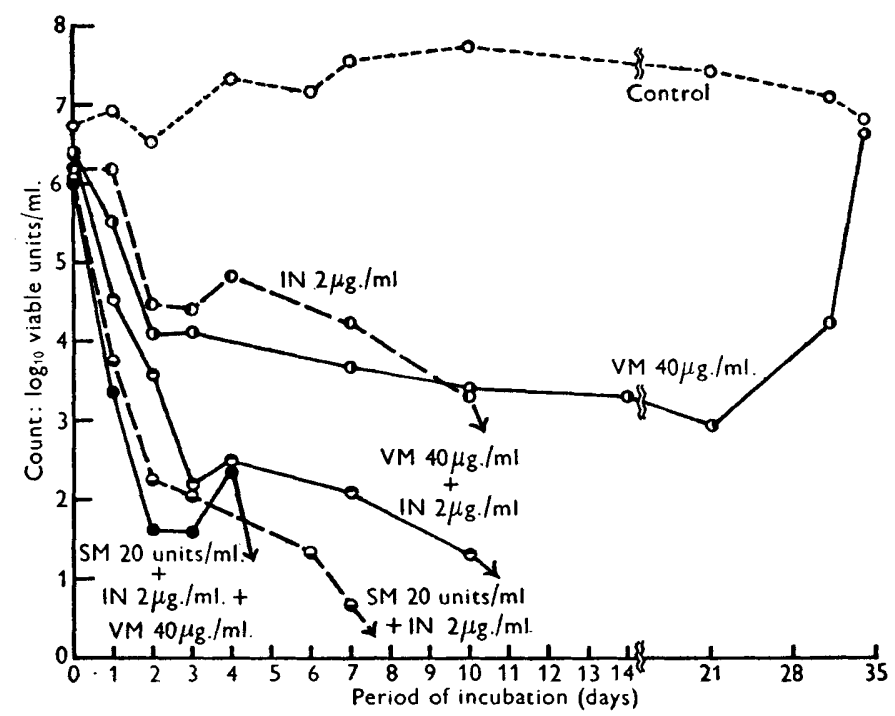

Fig. 5. Bactericidal activities of combinations of viomycin with isoniazid or isoniazid and streptomycin. $\mathrm{IN}=$ isoniazid; $\mathrm{VM}=$ viomycin; $\mathrm{SM}=$ =streptomycin. 
In contrast, viomycin + isoniazid was distinctly more bactericidal than viomycin or isoniazid alone (Fig. 5), and the mixture was only slightly less active than streptomycin + isoniazid. It can also be seen from Fig. 5 that the triple combination of streptomycin, isoniazid and viomycin was more actively bactericidal than any of the double combinations.

\section{Resistance}

As can be seen in Figs. 1-4, resistant organisms usually began to multiply in those cultures which contained streptomycin, isoniazid or viomycin, between the 10th and 21st days. The emergence of resistant organisms was investigated by preparing a series of cultures containing streptomycin or isoniazid alone or mixed with oxytetracycline or with PAS, in the same manner as for those cultures used in the bactericidal tests. These cultures were incubated and examined at intervals. The presence of macroscopic growth was noted and confirmed by subculture on to Lowenstein-Jensen slopes and on to nutrient agar slopes as a test of purity. Sensitivity tests were carried out on samples of the growths that eventually occurred. All cultures which had been in contact with streptomycin or isoniazid were found to show some degree of resistance to these compounds. On the other hand, no cultures showed resistance to oxytetracycline; the highest resistance ratio found was 2 . The results obtained with these cultures are shown in Table 1 . It can be seen that the addition of oxytetracycline $10 \mu \mathrm{g} . / \mathrm{ml}$. did not influence the emergence of

Table 1. Appearance of macroscopic growth in cultures containing streptomycin, isoniazid, PAS or oxytetracycline

\begin{tabular}{|c|c|c|c|c|c|c|c|}
\hline \multirow{2}{*}{$\begin{array}{c}\text { Strepto- } \\
\text { mycin } \\
\text { (units/ml.) }\end{array}$} & \multirow{2}{*}{$\begin{array}{r}\text { Isoniazid } \\
(\mu \mathrm{g} . / \mathrm{ml} .)\end{array}$} & \multirow{2}{*}{$\begin{array}{l}\text { Sodium } \\
\text { PAS } \\
\text { dihydrate } \\
(\mu \mathrm{g} . / \mathrm{ml} .)\end{array}$} & \multirow{2}{*}{$\begin{array}{c}\text { Oxytetra- } \\
\text { cycline } \\
(\mu \mathrm{g} \cdot / \mathrm{ml} .)\end{array}$} & \multirow{2}{*}{$\begin{array}{c}\text { Period of } \\
\text { incubation } \\
\text { (days) }\end{array}$} & \multirow{2}{*}{$\begin{array}{c}\text { Total } \\
\text { cultures }\end{array}$} & \multicolumn{2}{|c|}{$\begin{array}{l}\text { Cultures with } \\
\text { macroscopic growth }\end{array}$} \\
\hline & & & & & & Number & $\%$ \\
\hline 2 & - & - & - & $101-104$ & 19 & 17 & 89 \\
\hline 2 & - & - & 10 & 104 & 10 & 9 & 90 \\
\hline 2 & - & 10 & - & 86 & 12 & 9 & 75 \\
\hline 2 & - & 100 & - & 86 & 11 & 6 & 55 \\
\hline 20 & - & - & - & 136 & 10 & 2 & 20 \\
\hline 20 & - & - & 10 & 136 & 9 & 3 & 33 \\
\hline 20 & - & 100 & - & 40 & 2 & 0 & 0 \\
\hline - & $0 \cdot 2$ & - & - & 58 & 5 & 5 & 100 \\
\hline- & $0 \cdot 2$ & 10 & - & 73 & 1 & 1 & 100 \\
\hline- & $0 \cdot 2$ & 100 & - & 58 & 10 & 10 & 100 \\
\hline - & 2 & - & - & $58-103$ & 20 & 20 & 100 \\
\hline - & 2 & - & 10 & $\tilde{58}$ & 10 & 10 & 100 \\
\hline- & 2 & 100 & - & 103 & 12 & 0 & 0 \\
\hline
\end{tabular}

organisms resistant to streptomycin or to isoniazid. On the other hand, the suppression of the emergence of resistant organisms by admixture with PAS was complete when PAS + streptomycin or PAS + isoniazid were present at high concentrations equal to the maximal concentrations found in the serum of treated patients. Lower concentrations of PAS + streptomycin or of 
PAS + isoniazid were less effective in preventing the growth of resistant organisms; this confirms previous observations (Singh \& Mitchison, 1955). Of the cultures shown in Fig. 3, those containing viomycin alone and viomycin + oxytetracycline both yielded strains resistant to viomycin (resistance ratios of 8 and 16) at 30 days. The culture containing viomycin + PAS yielded no growth at $\mathbf{3 0}$ days.

\section{DISCUSSION}

In confirmation of the observations of Mackaness \& Smith (1953), oxytetracycline alone was found to have no bactericidal activity against the test organism Mycobacterium tuberculosis, strain H37Rv. Mixed with isoniazid or viomycin, oxytetracycline prevented their bactericidal action almost completely. These findings suggest that, in clinical practice, the eventual killing of the mycobacteria by these combinations would depend largely upon the host's defence mechanisms. Rist (1953) found that oxytetracycline + isoniazid was much less effective in the treatment of experimental infections in mice than was isoniazid alone. Tucker (1954) reported that viomycin +oxytetracycline was less effective in the treatment of human pulmonary tuberculosis than was viomycin + isoniazid, streptomycin or PAS. The in vitro antagonism between oxytetracycline and streptomycin was less marked. There is some evidence, although based on retrospective clinical comparisons, that streptomycin +oxytetracycline is of the same order of effectiveness as streptomycin + PAS in the treatment of pulmonary tuberculosis in man (Miller et al. 1952, 1954).

The eventual growth of resistant mycobacteria in cultures containing streptomycin + oxytetracycline, isoniazid + oxytetracycline or viomycin + oxytetracycline was presumably due to inactivation of the oxytetracycline. Thus it is not possible to conclude that in clinical practice such mixtures would be ineffective in delaying or preventing the emergence of resistance, since active concentrations of oxytetracycline would be maintained in the lesions by repeated dosage. Nevertheless, the closely similar incidence of resistance to streptomycin which developed in cultures exposed to streptomycin alone or to streptomycin +oxytetracycline suggests that the slight bactericidal activity of the mixture affected only those organisms which were sensitive to streptomycin and not the few streptomycin-resistant mutant organisms which were present initially in the cultures. Thus, during treatment with streptomycin + oxytetracycline, the streptomycin-resistant organisms initially present would be prevented from growing by the oxytetracycline, but might remain as a potential menace to the host.

In contrast to the antagonistic activity of oxytetracycline and in confirmation of earlier work (Singh \& Mitchison, 1955), PAS, which also has no bactericidal activity under the conditions employed, was found to be either slightly synergistic with each of the three compounds, streptomycin, isoniazid and viomycin, or not to influence their bactericidal activity. Streptomycin and isoniazid have been shown to have little bactericidal activity on resting cultures (Middlebrook \& Yegian, 1946; Tison, 1950; Schaeffer, 1954). It is possible that 
oxytetracycline may also produce resting conditions in cultures, so accounting for its antagonistic activity. On the other hand, Sievers (1949) and Rist (1953) claim that tubercle bacilli exposed to PAS multiply for a few generations before bacteriostasis occurs; the bactericidal compounds may be able to kill the organisms during this phase of multiplication.

Hobby et al. (1951 a) reported that subinhibitory concentrations of viomycin were sometimes sufficient to decrease significantly the concentrations of streptomycin required to inhibit growth of tubercle bacilli. No synergistic bactericidal activity was, however, found in the present work in the mixture viomycin $40 \mu \mathrm{g} . / \mathrm{ml}$. + streptomycin $20 \mathrm{units} / \mathrm{ml}$., nor was any synergistic effect observed when the two compounds together were used in lower concentrations in a further unreported experiment. The mixture of these two compounds, however, prevented the development of resistant strains. A mixture of viomycin + PAS also prevented the growth of viomycin-resistant strains, which may explain the observation of Pitts et al. (1953) that, in the chemotherapy of pulmonary tuberculosis, viomycin + PAS was superior to viomycin or streptomycin alone. Viomycin +isoniazid was more bactericidal than viomycin or isoniazid alone. The degree of synergism was, however, less than that observed with streptomycin + isoniazid. The mixture viomycin + streptomycin + isoniazid was more bactericidal than any two together.

\section{REFERENCES}

Bryson, V. \& Demerec, M. (1950). Patterns of resistance to antimicrobial agents. Ann. N.Y. Acad. Sci. 53, 283.

Des Autels, E. J. (1953). The effect of terramycin in delaying the emergence of bacillary resistance to streptomycin. U.S. Veterans Administration. Trans. 12 th Conf. Chemotherapy Tuberculosis, Washington, D.C. p. 304.

Gunnison, J. B., Coleman, V. R. \& JAwetz, E. (1950). Interference of aureomycin and terramycin with action of penicillin in vitro. Proc. Soc. exp. Biol., N.Y. 75, 549.

Hackney, R. L., King, E. Q., Marshall, E. E., Harden, K. \& Payne, H. M. (1953). Clinical observations on viomycin sulphate in the treatment of tuberculosis. Dis. Chest. 24, 591.

Новву, G. I. (1953). Viomycin. Summary of a four-year evaluation. U.S. Veterans Administration. Trans. 12th Conf. Chemotherapy Tuberculosis, Washington, D.C. p. 300.

Hobby, G. L., Lenert, T. F., Donikian, M. \& Pikula, D. (1951 $a$ ). The activity of viomycin against Mycobacterium tuberculosis and other microorganisms in vitro and in vivo. Amer. Rev. Tuberc. 63, 17.

Hobby, G. L., Lenert, T. F., Donikian, M. \& Pikula, D. (1951 b). The tuberculostatic activity of terramycin. Amer. Rev. Tuberc. 63, 434.

JAwetz, E., Gunnison, J. B. \& Speck, R. S. (1951). Studies on antibiotic synergism and antagonism: interference of aureomycin, chloramphenicol and terramycin with action of streptomycin. Amer. J. med. Sci. 222, 404.

KarLSON, A. G. \& GaINer, J. H. (1951). The effect of viomycin in tuberculosis of guinea-pigs including in vitro effects against tubercle bacilli resistant to other drugs. Amer. Rev. Tuberc. 63, 36.

Mackaness, G. B. \& Smith, N. (1953). The bactericidal action of isoniazid, streptomycin and terramycin on extracellular and intracellular tubercle bacilli. Amer. Rev. Tuberc. 67, 322. 
Medical Research Council (1953). Laboratory techniques for the determination of sensitivity of tubercle bacilli to isoniazid, streptomycin and PAS. Lancet, ii, 213.

Middlebrook, G. \& Yegian, D. (1946). Certain effects of streptomycin on mycobacteria in vitro. Amer. Rev. Tuberc. 54, 553.

Miller, F. L., Sands, J. H., Gregory, L. J., Hightower, J. A., Weisser, O. L. \& TEMPEL, C. W. (1954). Daily oxytetracycline (terramycin) and intermittent streptomycin in the treatment of pulmonary tuberculosis. Amer. Rev. Tuberc. 69, 58.

Miller, F. L., Sands, J. H., Walker, R., Dye, W. E. \& Tempel, C. W. (1952). Combined daily terramycin and intermittent streptomycin in the treatment of pulmonary tuberculosis. Amer. Rev. Tuberc. 66, 534.

Mrtchison, D. A. (1954). Problems of drug resistance. Brit. med. Bull. 10, 115.

Pfefer, L. M., Hughes, F. J. \& Dye, W. E. (1952). Terramycin in the treatment of pulmonary tuberculosis: A pilot study. Dis. Chest. 21, 123.

Pitts, F. W., O'Dell, E. T., Fitzpatrick, M. J., Dye, W. E., Hughes, F. J. \& Tempes, C. W. (1953). Intermittent viomycin therapy in pulmonary tuberculosis. Dis. Chest. 23, 241.

Regna, P. P. \& Solomons, I. A. (1950). Chemical and physical properties of terramycin. Ann. N.Y. Acad. Sci. 53, 229.

RIST, N. (1953). The application to clinical practice of the laboratory experience with combinations of antituberculosis drugs. Bull. Un. int. Tuberc. 23, 416.

Rothstein, E. \& Johnson, M. P. (1954). Streptomycin and oxytetracycline (terramycin) in the treatment of pulmonary tuberculosis. Amer. Rev. Tuberc. 69, 65.

SchatfFer, W. B. (1954). The effect of isoniazid on growing and resting tubercle bacilli. Amer. Rev. Tuberc. 69, 125.

Sievers, O. (1949). Sensitivity of tubercle bacillus. Lancet, i, 798.

SINGH, B. (1954). The synergistic and antagonistic action of chemotherapeutic agents on the tubercle bacillus in vitro. Ph.D. thesis. University of London.

Singh, B. \& Mitchison, D. A. (1954). Bactericidal activity of streptomycin and isoniazid against tubercle bacilli. Brit. med. $J . \mathrm{i}, 130$.

Singh, B. \& Mitchison, D. A. (1955). Bactericidal activity of streptomycin and isoniazid with para-aminosalicylic acid against Mycobacterium tuberculosis. J. gen. Microbiol. 12, 76.

Soderholm, B. (1952). Clinical experiments with terramyein in the treatment of pulmonary tuberculosis. Acta. tuberc. scand. 27, 109.

Steenken, W. \& Wolinsky, E. (1951). Viomycin in experimental tuberculosis. Amer. Rev. Tuberc. 63, 30.

Stewart, S., Turnbull, F. W. A. \& Crofton, J. W. (1954). The use of oxytetracycline in preventing or delaying isoniazid resistance in pulmonary tuberculosis. Brit. med. J. ii, 1508.

Tison, F. (1950). Dissociation des pouvoirs 'bactériostatique' et 'bactéricide' de la streptomycine in vitro sur le bacille de Koch. Ann. Inst. Pasteur, 79, 100.

Tucker, W. B. (1954). Re-treatment of advanced pulmonary tuberculosis with viomycin. Amer. Rev. Tuberc. 70, 812.

Werner, C. A., Tompsett, R., Muschenheim, C. \& McDermotr, W. (1951). The toxicity of viomycin in humans. Amer. Rev. Tuberc. 63, 49.

Youmans, G. P. \& Youmans, A. S. (1951). The effect of viomycin in vitro and in vivo on Mycobacterium tuberculosis. Amer. Rev. Tuberc. 63, 25. 